\title{
Benzoquinone-Hydroquinone Couple for Flow Battery
}

\section{Citation}

Nawar, Saraf, Brian Huskinson, and Michael Aziz. 2013. "Benzoquinone-Hydroquinone Couple for Flow Battery." MRS Proceedings 1491 (January). doi:10.1557/opl.2012.1737.

\section{Published Version}

doi:10.1557/opl.2012.1737

\section{Permanent link}

http://nrs.harvard.edu/urn-3:HUL.InstRepos:27417435

\section{Terms of Use}

This article was downloaded from Harvard University's DASH repository, and is made available under the terms and conditions applicable to Open Access Policy Articles, as set forth at http:// nrs.harvard.edu/urn-3:HUL.InstRepos:dash.current.terms-of-use\#OAP

\section{Share Your Story}

The Harvard community has made this article openly available.

Please share how this access benefits you. Submit a story.

Accessibility 


\title{
Benzoquinone-Hydroquinone Couple for Flow Battery
}

\author{
Saraf Nawar, ${ }^{1}$ Brian Huskinson, ${ }^{2}$ and Michael Aziz ${ }^{2}$ \\ ${ }^{1}$ Harvard College, Cambridge, MA 02138, USA \\ ${ }^{2}$ Harvard School of Engineering and Applied Sciences, 29 Oxford Street, Cambridge, MA \\ 02138, USA
}

\begin{abstract}
At present, there is an ongoing search for approaches toward the storage of energy from intermittent renewable sources like wind and solar. Flow batteries have gained attention due to their potential viability for inexpensive storage of large amounts of energy. While the quinone/hydroquinone redox couple is a widely studied redox pair, its application in energy storage has not been widely explored. Because of its high reversibility, low toxicity, and low component costs, we propose the quinone/hydroquinone redox couple as a viable candidate for use in a grid-scale storage device. We have performed single-electrode tests on several quinone/hydroquinone redox couples, achieving current densities exceeding $500 \mathrm{~mA} / \mathrm{cm}^{2}$, which is acceptable for use in energy applications. We fabricated a full cell using para-benzoquinone at the positive electrode against a commercial fuel cell hydrogen electrode separated by a Nafion membrane. We evaluated its performance in galvanic mode, where it reached current densities as high as $150 \mathrm{~mA} / \mathrm{cm}^{2}$. The results from these studies indicate that the quinone/hydroquinone redox couple is a promising candidate for use in redox flow batteries.
\end{abstract}

\section{INTRODUCTION}

In recent years, there have been enormous annual increases in wind and solar power generation, and continued rapid increases are anticipated. Because these sources are intermittent, it is becoming crucial to find cost-effective means of grid-scale energy storage, so that the temporal profile of natural supply can be matched to the demand profile. Flow batteries have received recent attention for this purpose, due to our ability to decouple energy and power capacities in their design, thereby allowing for the optimal sizing of each capability independently [1]. They may also become competitive with $\mathrm{Pb}$-acid batteries for

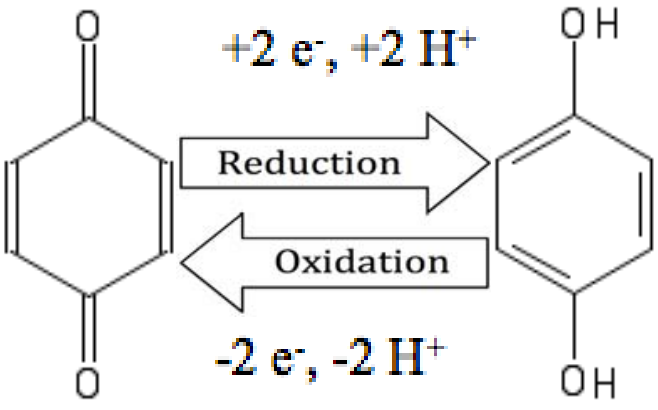

Figure 1. Reduction and oxidation mechanism for para-benzoquinone/ hydroquinone couple stationary storage applications such as off-grid storage of photovoltaically generated energy. Nevertheless, it remains a challenge to design a scalable energy storage system permitting very low cost per $\mathrm{kWh}$. The vanadium redox system, which has received the most attention, suffers from a high vanadium market price, which sets a floor on the ultimate capital cost per $\mathrm{kWh}$ [2]. We are investigating organic molecule-based electrochemical cells as cost-effective alternatives. In particular, quinones and their derivatives appear to be promising candidates as they offer low cost, low toxicity, and high reversibility in electrochemical reactions. Furthermore, quinones are already ubiquitously found in nature, as 
they play an active role in oxygen-evolving photosynthesis as part of the electron-transport chain in photosystem II [3]. Fig. 1 shows the mechanism for the oxidation and reduction of para-benzoquinone/para-hydroquinone couple in aqueous solution. The design of a fuel cell based on the quinone-hydroquinone redox couple would be an important step towards the realization of regenerative flow batteries based on small organic molecules.

In this report, we report on half-cell measurements of aqueous solutions of 1,4-("para")benzoquinone/hydroquinone and 1,2-("ortho")-benzoquinone in sulfuric acid and also present preliminary findings on studies of a fuel cell with one electrode composed of a quinone/hydroquinone couple. The present studies show that quinone chemistries constitute a promising approach to stationary energy storage.

\section{EXPERIMENTAL}

In order to study the redox behavior of the quinone/hydroquinone redox couple, we performed three-electrode tests using cyclic voltammetry (CV). For these electrochemical studies, we used a platinum wire as the working electrode, with a platinum metal strip as counter electrode. For the reference electrode, we used a silver chloride $(\mathrm{Ag} / \mathrm{AgCl})$ electrode with standard redox potential $E^{\circ}=0.210 \mathrm{~V}$ against SHE. We varied the potential from $0 \mathrm{~V}$ to $0.8 \mathrm{~V}$ vs. $\mathrm{Ag} / \mathrm{AgCl}$ using a step rate of $500 \mathrm{mV} / \mathrm{s}$ and recorded the electrochemical behavior of a solution containing 1,4-para-benzoquinone and 1,4-para-hydroquinone at concentrations of $0.0925 \mathrm{M}$ and $0.0908 \mathrm{M}$, respectively. Electrochemical tests were also carried out on ortho-hydroquinone, i.e. catechol, at its solubility limit of $3.91 \mathrm{M}$, for which the potential was varied from $0 \mathrm{~V}$ to $1.000 \mathrm{~V}$ at a step rate of $250 \mathrm{mV} / \mathrm{s}$. All measurements on quinone/hydroquinone couples were carried out at $1 \mathrm{~N} \mathrm{H}_{2} \mathrm{SO}_{4}$ (Sigma Aldrich, Inc.) solution.

For our full cell measurements, we used a fuel cell test bench constructed by Sustainable Innovations, LLC, and modified in our lab. It was used previously for studies on an $\mathrm{H}_{2}-\mathrm{Cl}_{2}$ regenerative fuel cell [4]. Fig. 2 shows an image of the cell used. The cell featured aluminum endplates, pyrolytic graphite current collectors with serpentine flow channels, a $50 \mu \mathrm{m}$ thick Nafion 212 proton exchange membrane (which prior to use was pretreated using methods previously described [4]), and PTFE/Viton tubing and gasketing throughout. On both sides of the cell, a commercial $\mathrm{Pt}-\mathrm{Ru} / \mathrm{C}$ carbon paper commercial electrode was used. To study the effect of temperature on cell performance, both the cell and liquid quinone reservoir were heated using a hot plate.

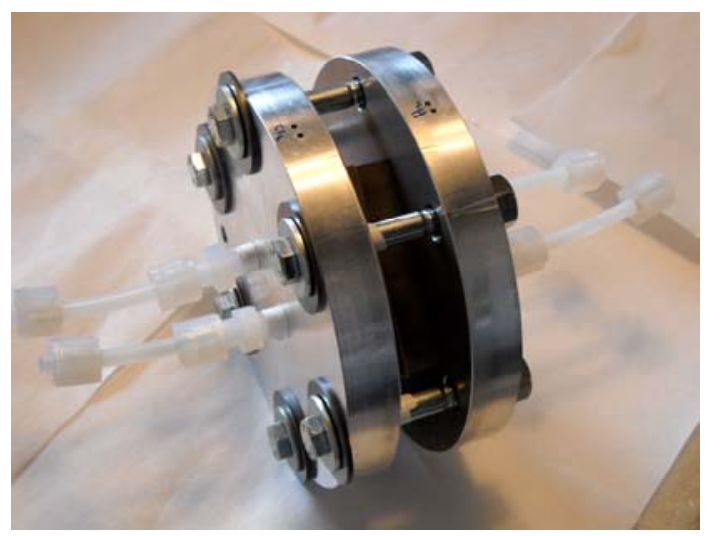

Figure 2. Image of the cell used for full cell tests 
For the present study, the cell was operated in galvanic mode using previously described methods [4], with high-purity hydrogen gas flowed through the negative side of the cell at 5 psig and quinone solution flowed through the positive side using a Cole Parmer Masterflex pump. The solution consisted of para-benzoquinone in $1 \mathrm{~N} \mathrm{H}_{2} \mathrm{SO}_{4}$. Before each set of measurements, an $\mathrm{N}_{2}$ purge was performed to remove any remaining $\mathrm{O}_{2}$ and to ensure there were no leaks in the assembly. Flow rates on the quinone side were maintained at the maximum rate offered by the pump (43 $\mathrm{mL} / \mathrm{min})$. After reactant introduction to the cell, the voltage was allowed to stabilize for a few minutes, after which a DC electronic load was used to draw incrementally higher currents from the cell. In general, in order to allow the voltage to stabilize, we waited about 15 seconds after each change in current. Furthermore, in order to ensure reproducibility, each measurement was taken five times at every current density, and the results were averaged.

\section{RESULTS AND DISCUSSION}

\section{Half-cell Measurements}

In general, it is believed that the reduction of quinones in aqueous solutions proceeds via a simple $2 \mathrm{H}^{+}, 2 \mathrm{e}^{-}$addition process, while for aprotic solvents, the process is divided into two one-electron transfer steps [5]. The former case is prevalent for cases in which the proton concentration exceeds the quinone concentration, whereas for situations in which quinone concentration exceeds proton concentration, reduction of quinone (Q) often leads to equilibrium mix of $\mathrm{Q}_{2}^{-}, \mathrm{QH}^{-}$, and $\mathrm{QH}_{2}$ species [5].

Fig. 3 shows the results of half-cell measurements on para-benzoquinone and parahydroquinone at concentrations of $0.0925 \mathrm{M}$ and $0.0918 \mathrm{M}$, respectively, in a $1 \mathrm{~N} \mathrm{H}_{2} \mathrm{SO}_{4}$ solution at $20^{\circ} \mathrm{C}$. We see prominent reduction and oxidation peaks for the couple at $0.69 \mathrm{~V}$ and $0.17 \mathrm{~V}$, respectively, which is consistent with the previously-observed electrochemical behavior of the para-benzoquinone/para-hydroquinone couple $[5,6]$. The reduction potential is given to be $0.43 \mathrm{~V}$ vs. $\mathrm{Ag} / \mathrm{AgCl}$ electrode, or equivalently, $0.64 \mathrm{~V}$ vs. SHE. We further explore the electrochemical behavior of ortho-hydroquinone at its solubility limit $(3.91 \mathrm{M})$ in aqueous solution. Here, we observe asymmetric oxidation and reduction peaks, achieving current

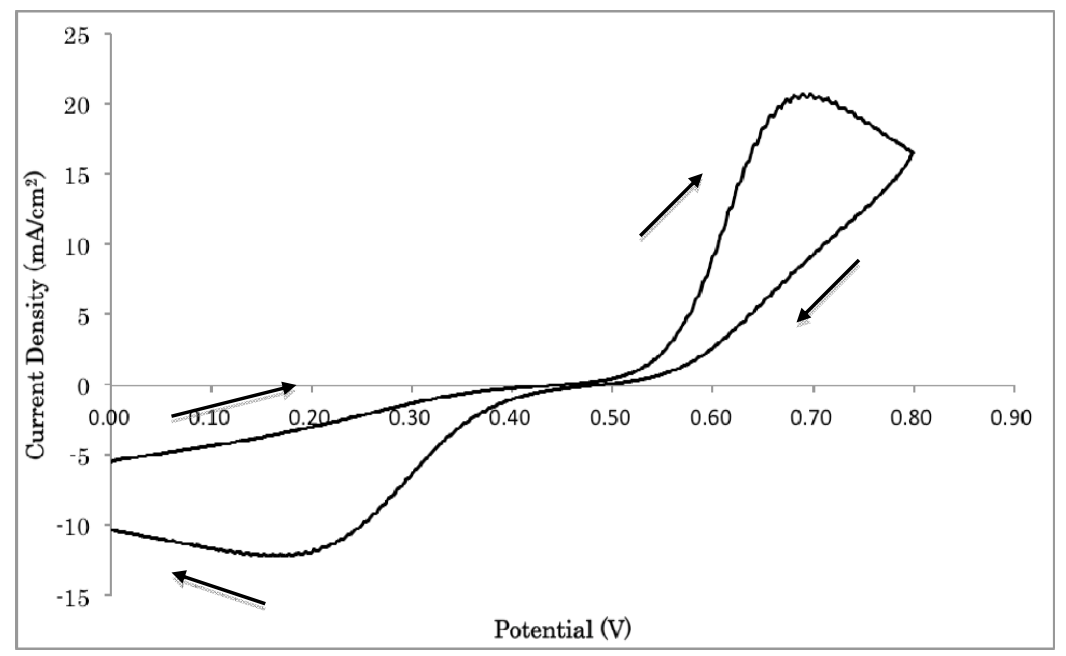

Figure 1. Cyclic voltammogram of para-benzoquinone/hydroquinone at $0.09 \mathrm{M}$ concentration of oxidized and reduced species. Scan rate is at $500 \mathrm{mV} / \mathrm{s}$. 


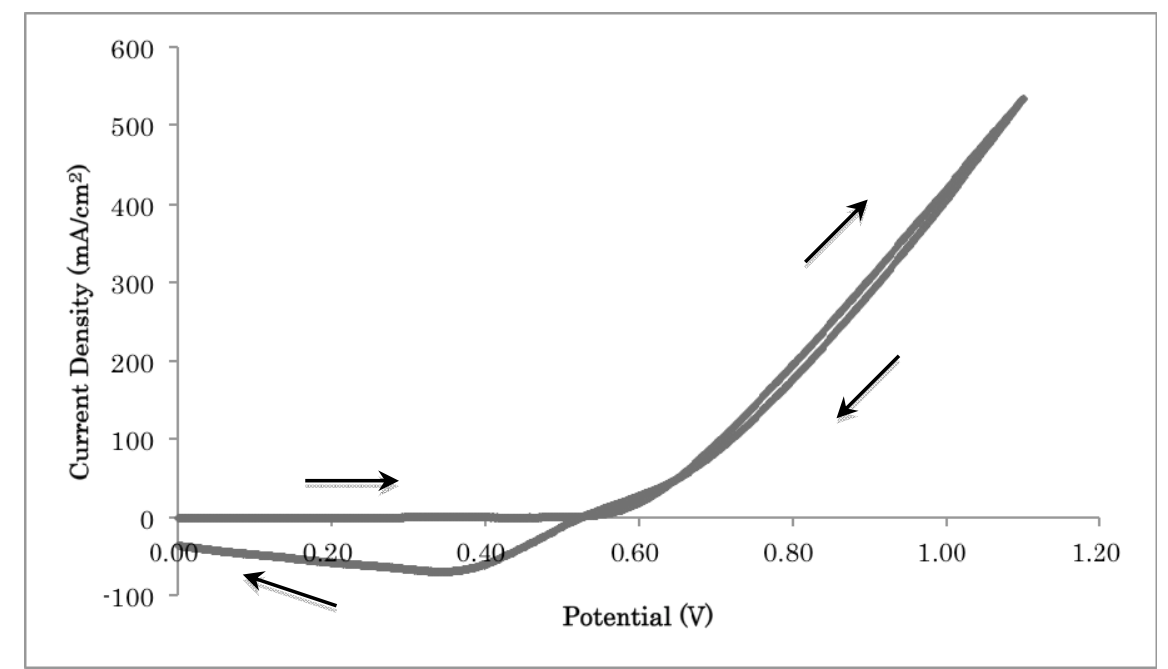

Figure 2. Cyclic voltammogram of ortho-hydroquinone at its aqueous solubility limit with a 250 $\mathrm{mV} / \mathrm{s}$ scan rate.

densities above $500 \mathrm{~mA} / \mathrm{cm}^{2}$ for the former. The asymmetric shape of the curve in Fig. 4 arises because we start at $(0,0)$ with $100 \%$ ortho-hydroquinone and no ortho-benzoquinone available to reduce, sweep up to $(1.1 \mathrm{~V}, 550 \mathrm{~mA})$, thereby oxidizing ortho-hydroquinone to produce a small amount of ortho-benzoquinone which is subsequently reduced to ortho-hydroquinone when the sweep returns to low potential. The limited solubility of ortho-benzoquinone $(0.06 \mathrm{M})$ compared to its reduced form precludes symmetric behavior at high concentration. The redox potential here appears to be $0.54 \mathrm{~V}$ vs $\mathrm{Ag} / \mathrm{AgCl}$, or $0.75 \mathrm{vs} \mathrm{SHE}$, which is higher than that for parabenzoquinone. The high current densities achieved indicate that quinone/hydroquinone couples are promising candidates for redox flow battery application.

\section{$\underline{\text { Full-cell Measurements }}$}

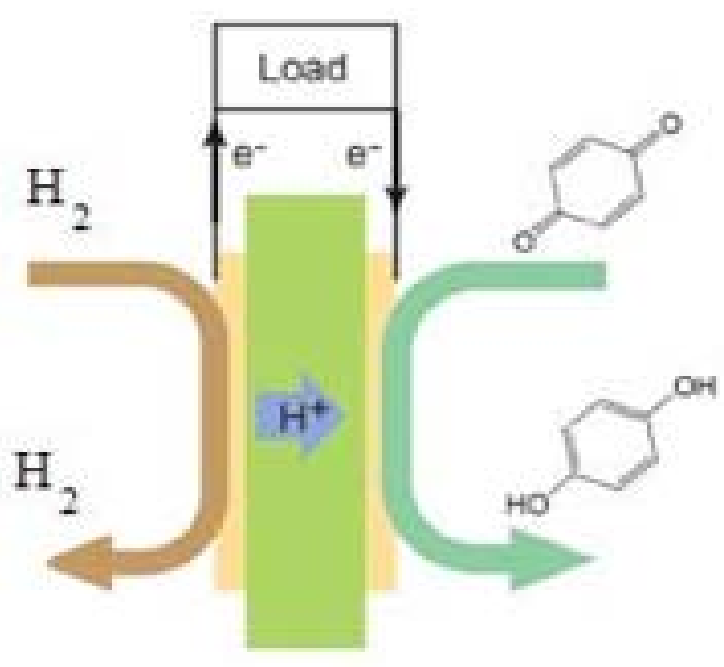

Figure 3. Schematic for hydrogen-quinone fuel cell operation in discharge mode.
As shown in the schematic in Fig. 5, we used p-benzoquinone as the positive material and $\mathrm{H}_{2}$ gas as the negative material for fuel cell tests. We operated the cell in discharge mode, with the p-benzoquinone / p-hydroquinone mixture recirculated past the quinone electrode on the positive side, and $\mathrm{H}_{2}$ flowing past the hydrogen electrode. The Nafion membrane conducted $\mathrm{H}^{+}$ions towards the cathode. The cell reached current densities of about 150 $\mathrm{mA} / \mathrm{cm}^{2}$ and power densities of about 35 $\mathrm{mW} / \mathrm{cm}^{2}$, which are higher than values previously reported using soluble quinones for the positive electrode in a full cell configuration [7]. In Fig. 6, we show the cell potential versus current density for 
tests done using a $0.1 \mathrm{M}$ solution. These tests were done at room temperature and at $52{ }^{\circ} \mathrm{C}$. In general, we observed a nearly linear drop in potential with increasing current density -especially for low current densities -- indicating robust electrode kinetics for the redox reaction, i.e. relatively low activation overpotentials.

In Fig. 7, we show the cell power density as a function of galvanic current density. For measurements taken at room temperature, the power density falls off rapidly near the limiting current density. As expected, we find that increased temperature leads to improved cell performance, as we are able to achieve both increased power densities and limiting current densities with increased temperature.

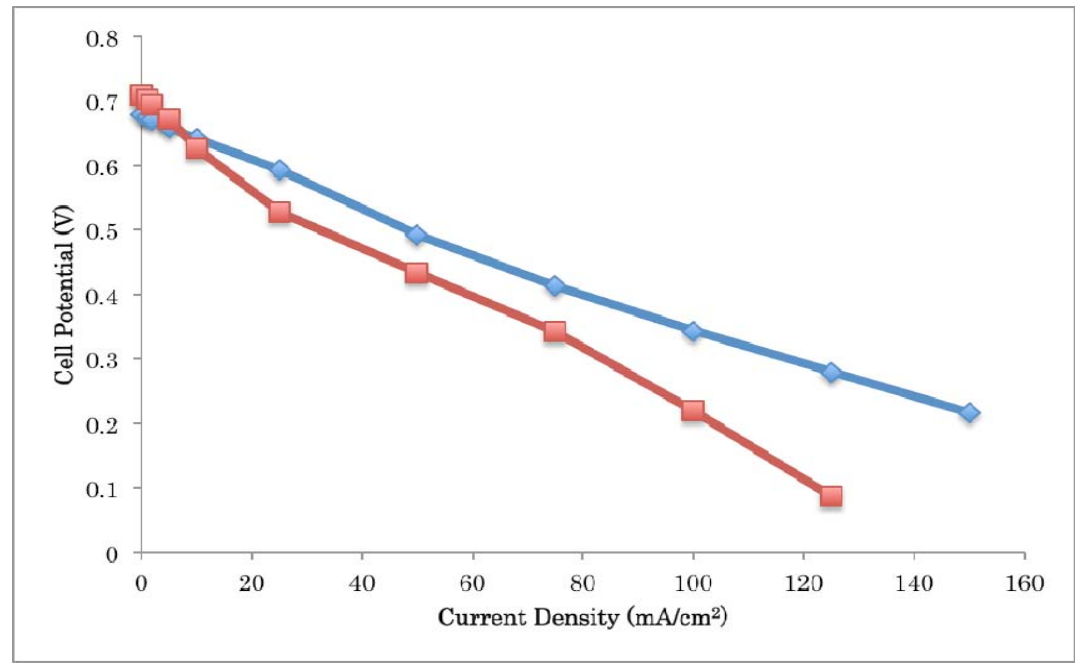

Figure 6. Cell potential versus galvanic current density for the fuel cell. Tests were performed using a solution of $0.1 \mathrm{M}$ p-benzoquinone in $1 \mathrm{~N} \mathrm{H}_{2} \mathrm{SO}_{4}$ on the cathode side and $\mathrm{H}_{2}$ gas on the anode side. Squares: $20^{\circ} \mathrm{C}$; diamonds: $52^{\circ} \mathrm{C}$.

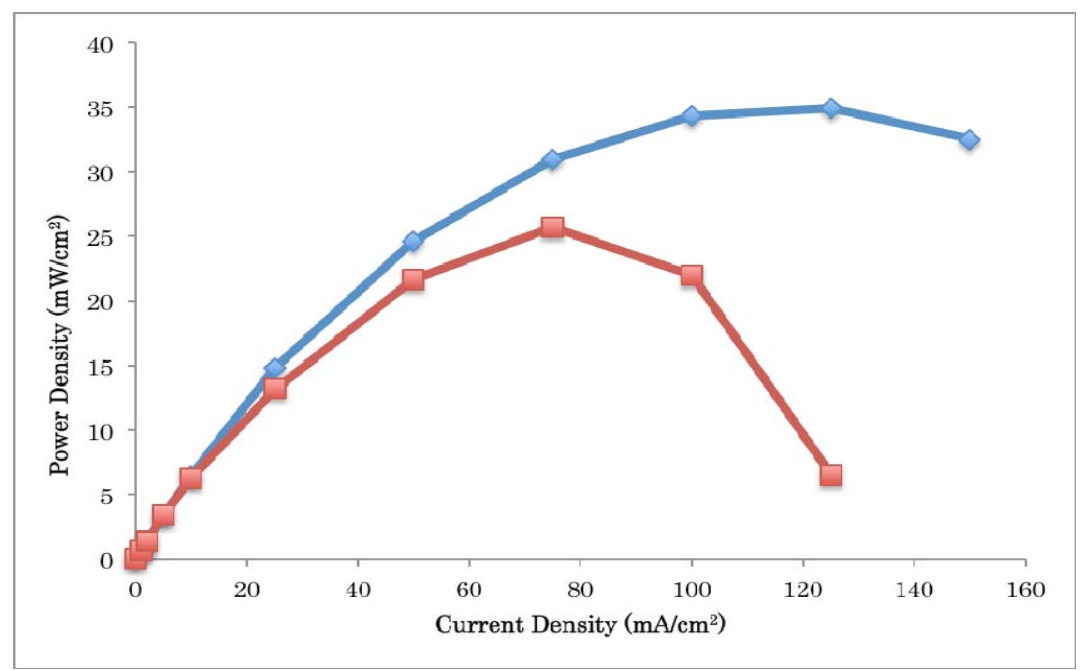

Figure 7. Power density versus galvanic current density. Squares: $20{ }^{\circ} \mathrm{C}$; diamonds: $52{ }^{\circ} \mathrm{C}$. 


\section{CONCLUSIONS}

We have demonstrated a redox flow battery based on the quinone-hydroquinone redox couple in low $\mathrm{pH}$ aqueous solutions using quinone/hydroquinone on the positive electrode and $\mathrm{H}_{2} / \mathrm{H}+$ on the negative electrode. The present results from half-cell and full cell measurements, indicating robust electrode kinetics of the quinone/hydroquinone couple, appear highly promising for flow battery applications. Because it appears that the current density is limited by the quinone solubility, we are developing high-solubility quinones. In addition, because the power density is limited by the current density and, furthermore, by the equilibrium voltage, we are also currently developing quinones with redox potentials suitable for use at the negative electrode. This could lead to an all-quinone/hydroquinone flow battery, which would provide a path towards very inexpensive stationary energy storage.

\section{ACKNOWLEDGMENTS}

We thank Prof. Theodore Betley for helpful conversations. This work was supported by the Harvard University Center for the Environment and the Harvard School of Engineering and Applied Sciences. S.N. was supported in part by the Physics Department at Harvard University. B.H. was supported in part by an NSF Graduate Research Fellowship.

\section{REFERENCES}

1. J. Rugolo and M. J. Aziz, Energy \& Environmental Science 5, 7151 (2012).

2. T. Nguyen and R.F. Savinell, "Flow Batteries", Electrochemical Society Interface 19, 54 (2010).

3. F. Müh, C. Glöckner, J. Hellmich, and A. Zouni, Biochimica et Biophysica Acta 44, 1817 (2012).

4. B. Huskinson, J. Rugolo, S. Mondal, and M.J. Aziz, Energy \& Environmental Science 5, 8690 (2012).

5. M. Quan, D. Sanchez, M.F. Wasylkiw, and D. Smith. J. Am. Chem. Soc. 129, 12847 (2007).

6. M. Rafiee and D. Nematollahi. Electroanalysis 19, 1382, (2007).

7. Y. Xu, Y. Wen, J. Cheng, Y. Yanga, Z. Xie, and G. Cao. "Novel Organic Redox Flow Batteries Using Soluble Quinonoid Compounds as Positive Materials," in World Non-GridConnected Wind Power and Energy Conference (Nanjing, China, 2009), pp.1 